\title{
Simulation of nitrate, sulfate, and ammonium aerosols over the United States
}

\author{
J. M. Walker ${ }^{1}$, S. Philip ${ }^{3}$, R. V. Martin ${ }^{3,4}$, and J. H. Seinfeld ${ }^{1,2}$ \\ ${ }^{1}$ Department of Environmental Science and Engineering, California Institute of Technology, Pasadena, California, USA \\ ${ }^{2}$ Department of Chemical Engineering, California Institute of Technology, Pasadena, California, USA \\ ${ }^{3}$ Department of Physics and Atmospheric Science, Dalhousie University, Halifax, Nova Scotia, Canada \\ ${ }^{4}$ Harvard-Smithsonian Center for Astrophysics, Cambridge, Massachusetts, USA
}

Correspondence to: J. H. Seinfeld (seinfeld@caltech.edu)

Received: 19 July 2012 - Published in Atmos. Chem. Phys. Discuss.: 6 August 2012

Revised: 16 November 2012 - Accepted: 19 November 2012 - Published: 27 November 2012

\begin{abstract}
Atmospheric concentrations of inorganic gases and aerosols (nitrate, sulfate, and ammonium) are simulated for 2009 over the United States using the chemical transport model GEOS-Chem. Predicted aerosol concentrations are compared with surface-level measurement data from the Interagency Monitoring of Protected Visual Environments (IMPROVE), the Clean Air Status and Trends Network (CASTNET), and the California Air Resources Board (CARB). Sulfate predictions nationwide are in reasonably good agreement with observations, while nitrate and ammonium are over-predicted in the East and Midwest, but underpredicted in California, where observed concentrations are the highest in the country. Over-prediction of nitrate in the East and Midwest is consistent with results of recent studies, which suggest that nighttime nitric acid formation by heterogeneous hydrolysis of $\mathrm{N}_{2} \mathrm{O}_{5}$ is over-predicted based on current values of the $\mathrm{N}_{2} \mathrm{O}_{5}$ uptake coefficient, $\gamma$, onto aerosols. After reducing the value of $\gamma$ by a factor of 10 , predicted nitrate levels in the US Midwest and East still remain higher than those measured, and over-prediction of nitrate in this region remains unexplained. Comparison of model predictions with satellite measurements of ammonia from the Tropospheric Emissions Spectrometer (TES) indicates that ammonia emissions in GEOS-Chem are underestimated in California and that the nationwide seasonality applied to ammonia emissions in GEOS-Chem does not represent California very well, particularly underestimating winter emissions. An ammonia sensitivity study indicates that GEOS-Chem simulation of nitrate is ammonia-limited in southern California and much of the state, suggesting that an underestimate of
\end{abstract}

ammonia emissions is likely the main cause for the underprediction of nitrate aerosol in many areas of California. An approximate doubling of ammonia emissions is needed to reproduce observed nitrate concentrations in southern California and in other ammonia sensitive areas of California. However, even a tenfold increase in ammonia emissions yields predicted nitrate concentrations that are still biased low in the central valley of California. The under-prediction of nitrate aerosol in the central valley of California may arise in part from an under-prediction of both ammonia and nitric acid in this region. Since nitrate aerosols are particularly sensitive to mixed layer depths, owing to the gas-particle equilibrium, the nitrate under-prediction could also arise in part from a potential regional overestimate of GEOS-5 mixed layer depths in the central valley due to unresolved topography in this region.

\section{Introduction}

Nitrate $\left(\mathrm{NO}_{3}^{-}\right)$, sulfate $\left(\mathrm{SO}_{4}^{2-}\right)$ and ammonium $\left(\mathrm{NH}_{4}^{+}\right)$are major constituents of atmospheric aerosols. These species are formed primarily from chemical reactions in the atmosphere involving the gas-phase precursors, nitrogen oxides $\left(\mathrm{NO}_{\mathrm{x}}\right)$, sulfur dioxide $\left(\mathrm{SO}_{2}\right)$ and ammonia $\left(\mathrm{NH}_{3}\right)$. In this work, we use the global chemical transport model GEOSChem to simulate nitrate, sulfate and ammonium aerosols over the United States and we compare model predictions with measurement data to assess model performance. This work is motivated, in part, by previous studies (Pye et al., 


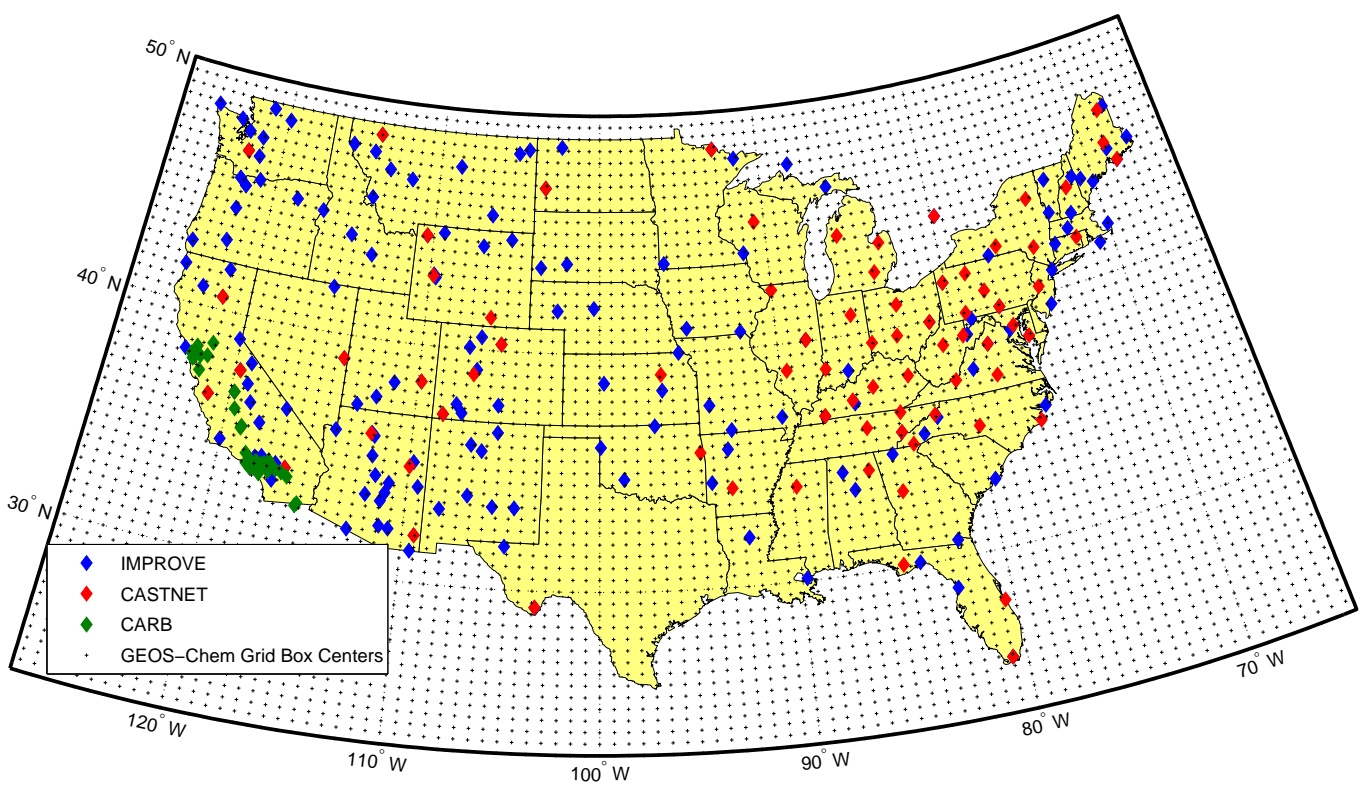

Fig. 1. Locations of IMPROVE, CASTNET, and CARB measurement sites, and GEOS-Chem grid box centers over the US.

2009; Bauer et al., 2007; Myhre et al., 2006) that indicated that observed high nitrate levels in California have not been simulated adequately by global chemical transport models. In a recent GEOS-Chem simulation over the US, Zhang et al. (2012) found that although predictions of the gas-phase precursor $\mathrm{NO}_{\mathrm{x}}$ agreed well with satellite measurements, predicted $\mathrm{HNO}_{3}$ and nitrate aerosol had strong positive biases throughout most of the country.

We note especially the study of Heald et al. (2012), completed at essentially the same time as the present work, which addresses a number of the same issues and reports results generally consistent with those presented here.

\section{GEOS-Chem model}

Atmospheric concentrations of aerosols and gas-phase species are simulated using the chemical transport model GEOS-Chem, version 9-01-02 (http://acmg.seas.harvard. edu/geos/). A nested version of the model (Chen et al., 2009; van Donkelaar et al., 2012; Zhang et al., 2012) is used, on a $1 / 2^{\circ}$ (latitude) by $2 / 3^{\circ}$ (longitude) horizontal grid over North America (Fig. 1), with 47 vertical levels, nested within a global parent grid at $2^{\circ} \times 2.5^{\circ}$ horizontal resolution. The calendar year 2009 is simulated, with a spin-up period of one year. The model is driven by Goddard Earth Observing System (GEOS-5) assimilated meteorological fields from NASA's Global Modeling and Assimilation Office (GMAO). Meteorological data include winds, temperature, humidity, cloud fraction, precipitation and other fields at a 6-h temporal resolution, as well as mixed layer depth and surface properties at a 3-h temporal resolution.
Data from the EPA National Emissions Inventory (NEI) 2005 on emissions of $\mathrm{NO}_{\mathrm{x}}, \mathrm{SO}_{2}, \mathrm{NH}_{3}, \mathrm{CO}$ and volatile organic compounds (VOCs) were scaled to the simulation year according to annual trends in the EPA Acid Rain Program (http://ampd.epa.gov/ampd/) and the NEI Air Pollutant Emissions Trends Data (http://www.epa.gov/ttn/chief/ trends/). Additional $\mathrm{NO}_{\mathrm{x}}$ and $\mathrm{SO}_{2}$ emission sources include aircraft, biofuel, and biomass burning, as well as emissions of $\mathrm{NO}_{\mathrm{x}}$ from lightning, soil and fertilizer, and sulfur emissions from ships, volcanoes and oceans (Park et al., 2004). Natural emission sources of ammonia include soil, vegetation and oceans, as described by Bouwman et al. (1997). Seasonal scaling factors, based on the EPA NEI 1999 emission inventory, were applied to emissions of all species except for $\mathrm{NO}_{\mathrm{x}}$, which was seasonally scaled based on the EPA Visibility Improvement-State and Tribal Association of the Southeast (VISTAS) emission inventory, and ammonia, which was seasonally scaled as in Park et al. (2004).

The model includes a detailed ozone- $\mathrm{NO}_{\mathrm{x}}$-VOC gas-phase chemical mechanism involving approximately 80 species and 300 chemical reactions (Bey et al., 2001). Sulfate formation pathways include gas-phase oxidation of $\mathrm{SO}_{2}$ by $\mathrm{OH}$ and aqueous-phase oxidation of $\mathrm{SO}_{2}$ by ozone and hydrogen peroxide. Gas-phase sulfur chemistry also includes oxidation of dimethyl sulfide (DMS) by $\mathrm{OH}$ to form $\mathrm{SO}_{2}$ and methanesulfonic acid, and oxidation of DMS by $\mathrm{NO}_{3}$ to form $\mathrm{SO}_{2}$ (Park et al., 2004). The partitioning between gas-phase and aerosol-phase nitrate, sulfate and ammonium is computed using ISORROPIA II (Fountoukis and Nenes, 2007), a thermodynamic equilibrium model for the $\mathrm{K}^{+}$$\mathrm{Ca}^{2+}-\mathrm{Mg}^{2+}-\mathrm{NH}_{4}^{+}-\mathrm{Na}^{+}-\mathrm{SO}_{4}^{2-}-\mathrm{NO}_{3}^{-}-\mathrm{Cl}^{-}-\mathrm{H}_{2} \mathrm{O}$ aerosol system, implemented within GEOS-Chem. 
Table 1. Measurement datasets.

\begin{tabular}{llll}
\hline Dataset & Site locations & $\begin{array}{l}\text { Sampling } \\
\text { frequency }\end{array}$ & Species measured \\
\hline IMPROVE & Remote/rural areas & $\begin{array}{l}\text { 24-h samples every } \\
\text { 3rd day }\end{array}$ & Fine particulate $(<2.5 \mu \mathrm{m})$ sulfate and nitrate \\
\hline CASTNET & Remote/rural areas & 7-day samples & $\begin{array}{l}\text { Total particulate }(\text { not size selective }) \text { sulfate, } \\
\text { nitrate and ammonium, } \mathrm{SO}_{2}(\mathrm{~g}), \mathrm{HNO}_{3}(\mathrm{~g})\end{array}$ \\
\hline CARB & Mostly urban & $\begin{array}{l}\text { 24-h samples every } \\
6 \text { days }\end{array}$ & $\begin{array}{l}\text { Fine particulate }(<2.5 \mu \mathrm{m}) \text { sulfate, nitrate, } \\
\text { and ammonium; } \mathrm{PM}_{10} \text { sulfate and nitrate }\end{array}$ \\
\hline
\end{tabular}

Removal of nitrate, sulfate, ammonium and related gasphase species through wet deposition and dry deposition is simulated. The wet deposition scheme includes scavenging of aerosols and soluble gases in wet convective updrafts, incloud scavenging by cloud droplets or ice crysals, and belowcloud scavenging by precipitation (Liu et al., 2001). Dry deposition is simulated with a resistance in series scheme (Weseley, 1989), with surface resistances for sulfate, nitrate and ammonium aerosols as described by Zhang et al. (2001).

Planetary boundary layer mixing is simulated using the TURBDAY full mixing scheme (Wu et al., 2007; Bey et al., 2001), in which vertical mixing is assumed to be instantaneous and uniform from the surface to the top of the mixed layer. The offline GEOS-5 meteorological fields used here display unrealistically low mixed layer depths at night, compared with observed mixed layer depths (Liu and Liang, 2010). This bias causes GEOS-5 driven GEOS-Chem simulations to predict an artificially large build up of aerosols at night and corresponding high biases in predicted daily and monthly average concentrations. To correct this issue, we have modified the model to define a minimum mechanical mixing depth, calculated based on the local friction velocity (Lin and McElroy, 2010; Koracin and Berkowicz, 1988; Heald et al., 2012); any GEOS-5 mixed layer depths below this value are set to the minimum mechanical mixing depth. This modification yields nighttime mixed layer depths that are more consistent with observations (Liu and Liang, 2010), and more realistic diurnal variations in predicted aerosol concentrations.

Zhang et al. (2012) suggest that nitrate concentrations may be over-predicted owing to an overestimate of nighttime nitric acid formation through heterogeneous $\mathrm{N}_{2} \mathrm{O}_{5}$ hydrolysis, $\mathrm{N}_{2} \mathrm{O}_{5}+\mathrm{H}_{2} \mathrm{O} \rightarrow 2 \mathrm{HNO}_{3}$, as $\mathrm{N}_{2} \mathrm{O}_{5}$ concentrations build up due to the gas phase reaction of $\mathrm{NO}_{2}$ with $\mathrm{NO}_{3}$. The rate of $\mathrm{HNO}_{3}$ production by this reaction is expressed as $2 k\left[\mathrm{~N}_{2} \mathrm{O}_{5}\right]$, where $k=\gamma v_{\mathrm{N}_{2} \mathrm{O}_{5}} A_{\text {Aerosol }} / 4$ and $v_{\mathrm{N}_{2} \mathrm{O}_{5}}$ is the mean molecular speed of $\mathrm{N}_{2} \mathrm{O}_{5}, A_{\text {Aerosol }}$ is the aerosol surface area per unit volume, and $\gamma$ is the uptake coefficient, which describes the probability that an $\mathrm{N}_{2} \mathrm{O}_{5}$ molecule impacting an aerosol particle will undergo the irreversible heterogeneous hydrolysis reaction (Seinfeld and Pandis, 2006).

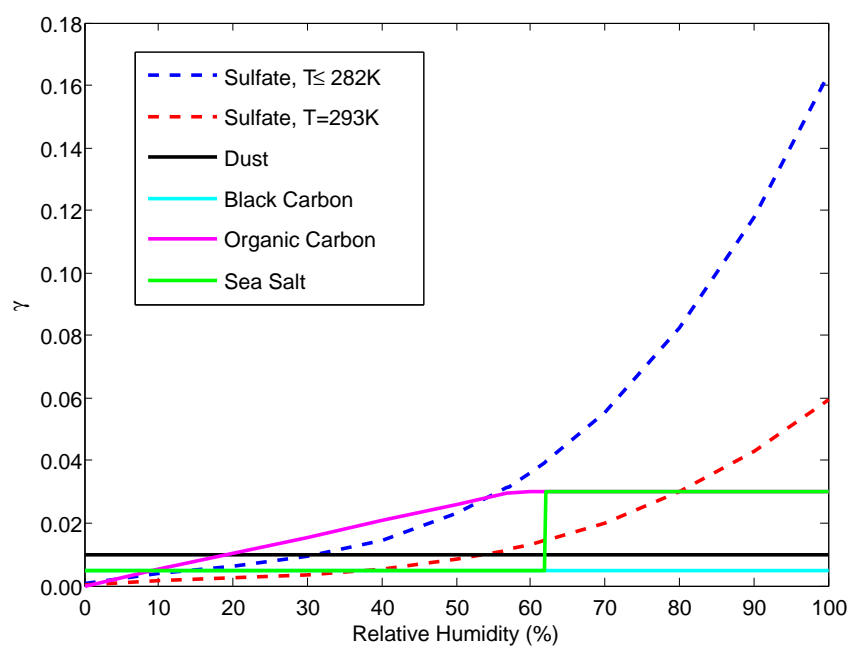

Fig. 2. Values of the $\mathrm{N}_{2} \mathrm{O}_{5}$ hydrolysis uptake coefficient $\gamma$ in GEOS-Chem (Evans and Jacob, 2005).

Macintyre and Evans (2010) list the range of published values for $\gamma$ as $10^{-4}$ to $>0.1$. They note that recent laboratory studies indicate lower values than previously considered, and suggest that the tropospheric value is likely in the range of 0.001 to 0.02 . In a sensitivity analysis with GEOS-Chem, they find that within this range of values, the production of $\mathrm{HNO}_{3}$ in the model is highly sensitive to the selected value of $\gamma$.

Figure 2 shows the values of $\gamma$ used in the standard version of GEOS-Chem, for the various types of aerosols on which heterogeneous $\mathrm{N}_{2} \mathrm{O}_{5}$ hydrolysis is simulated (Evans and Jacob, 2005). The uptake coefficient on sulfate aerosol is determined in GEOS-Chem as a function of temperature and relative humidity. For temperatures of $282 \mathrm{~K}$ and below, $\gamma$ at a given $\mathrm{RH}$ is assumed to be independent of temperature; for temperatures above $282 \mathrm{~K}, \gamma$ at a given $\mathrm{RH}$ decreases with increasing temperature. It is evident in Fig. 2 that the value of $\gamma$ is above 0.02 for organic carbon and sea salt aerosol, and well above 0.02 for sulfate aerosol at higher humidities, exceeding 0.1 at lower temperatures and high RH. Based on the recommendations of Macintyre and Evans (2010), the values of $\gamma$ in GEOS-Chem likely lead to an overestimate of 

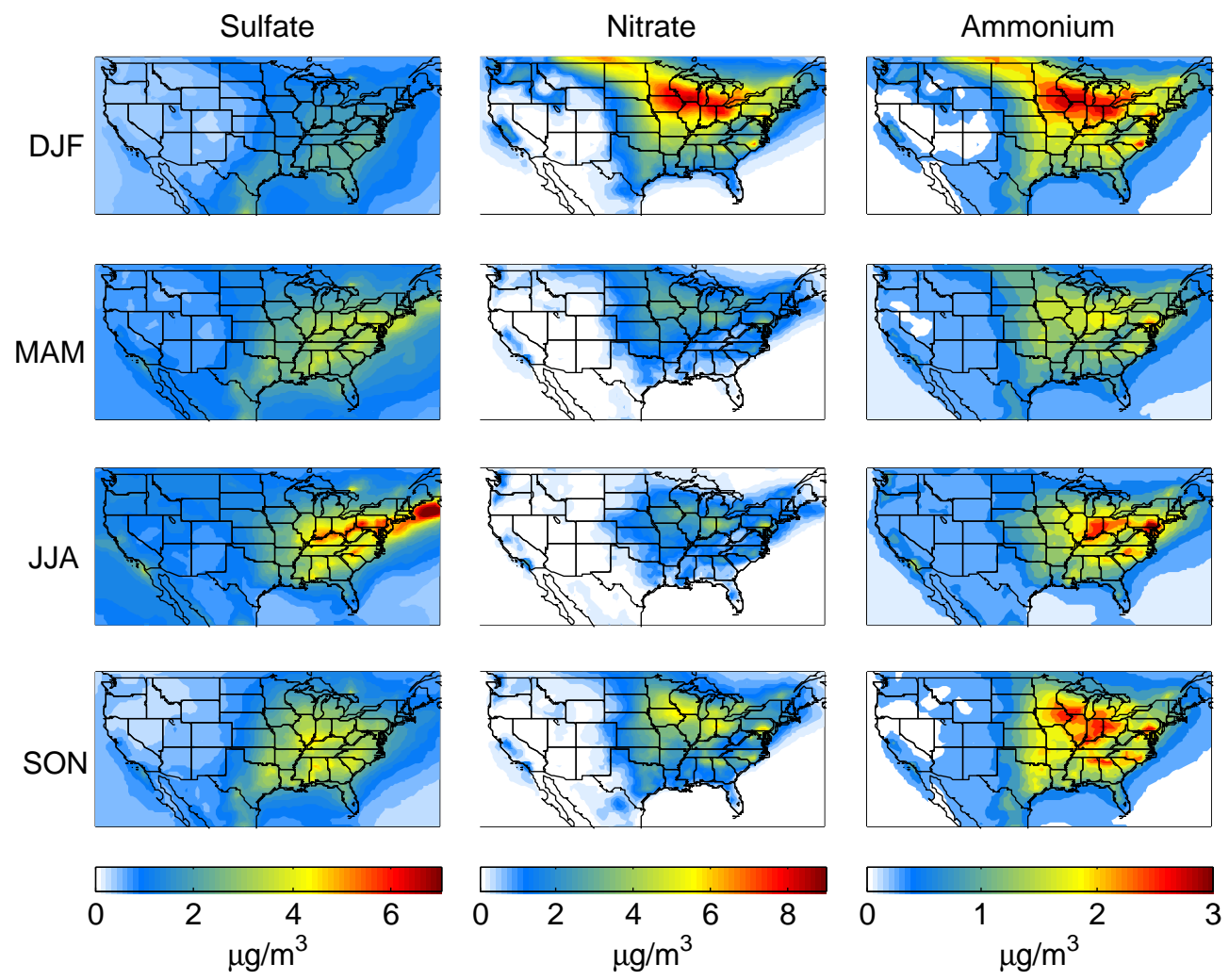

Fig. 3. Predicted concentrations of sulfate, nitrate, and ammonium aerosol for December-January-February (DJF), March-April-May (MAM), June-July-August (JJA) and September-October-November (SON), 2009.

nighttime $\mathrm{HNO}_{3}$ formation, with a corresponding overestimate of nitrate aerosol production. Following the approach of Zhang et al. (2012), we have reduced $\gamma$ by a factor of 10 in the present GEOS-Chem simulations, in order to simulate nighttime nitric acid formation using an uptake coefficient more consistent with Macintyre and Evans (2010).

\section{Surface-level atmospheric data}

GEOS-Chem simulations are compared to measured aerosol concentrations for 2009 from three data sources: the Interagency Monitoring of Protected Visual Environments (IMPROVE, http://views.cira.colostate.edu/web/DataWizard/), the Clean Air Status and Trends Network (CASTNET, http://views.cira.colostate.edu/web/DataWizard/) and the California Air Resources Board (CARB, http://www.arb.ca.gov/aqmis2/aqmis2.php). Table 1 summarizes the sampling frequency and measured species in each dataset. Locations of the measurement sites are shown in Fig. 1.

The CARB dataset includes sulfate and nitrate concentrations measured by both $\mathrm{PM}_{10}$ and $\mathrm{PM}_{2.5}$ samplers. GEOSChem secondary aerosol predictions are not size resolved; however for the purposes of this study they can be assumed to be in the fine mode $\left(\mathrm{PM}_{2.5}\right)$, since the model does not in- clude the formation of inorganic aerosols on coarse mode dust particles and although the model does include the formation of inorganic aerosols on coarse mode sea salt, these predicted concentrations comprise a negligible fraction of the total predicted aerosol concentrations over the continental US. Thus, the $\mathrm{PM}_{2.5}$ nitrate and sulfate measurements were selected from the CARB dataset for comparison with model predictions.

The precision of IMPROVE secondary inorganic aerosol concentration measurements is estimated to be 4-6\% (http: //vista.cira.colostate.edu/improve/Publications/OtherDocs/ IMPROVEDataGuide/IMPROVEDataGuide.htm). The precision of CASTNET concentration measurements is estimated to be approximately $3 \%, 8 \%$, and $4 \%$ for sulfate, nitrate, and ammonium, respectively (Sickles II and Shadwick, 2002). Since the CARB $\mathrm{PM}_{2.5}$ samplers are similar to the IMPROVE samplers, measurement precision for CARB observations is assumed to be similar to those in IMPROVE.

\section{Results}

Figure 3 shows the predicted seasonal average concentrations of nitrate, sulfate and ammonium aerosol at the surface level. Predicted annual concentrations are compared with measurements over the entire US in Fig. 4 and over California in 

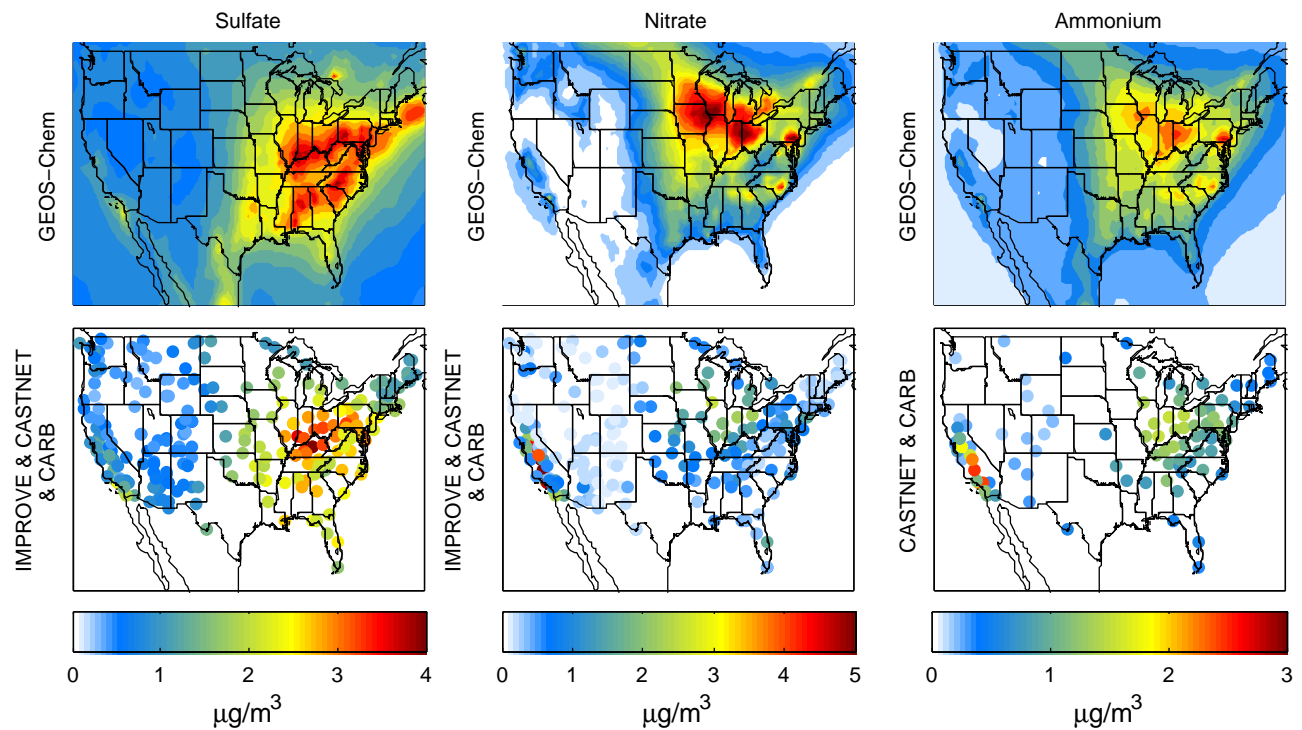

Fig. 4. Predicted 2009 annual mean aerosol concentrations compared with measured concentrations.
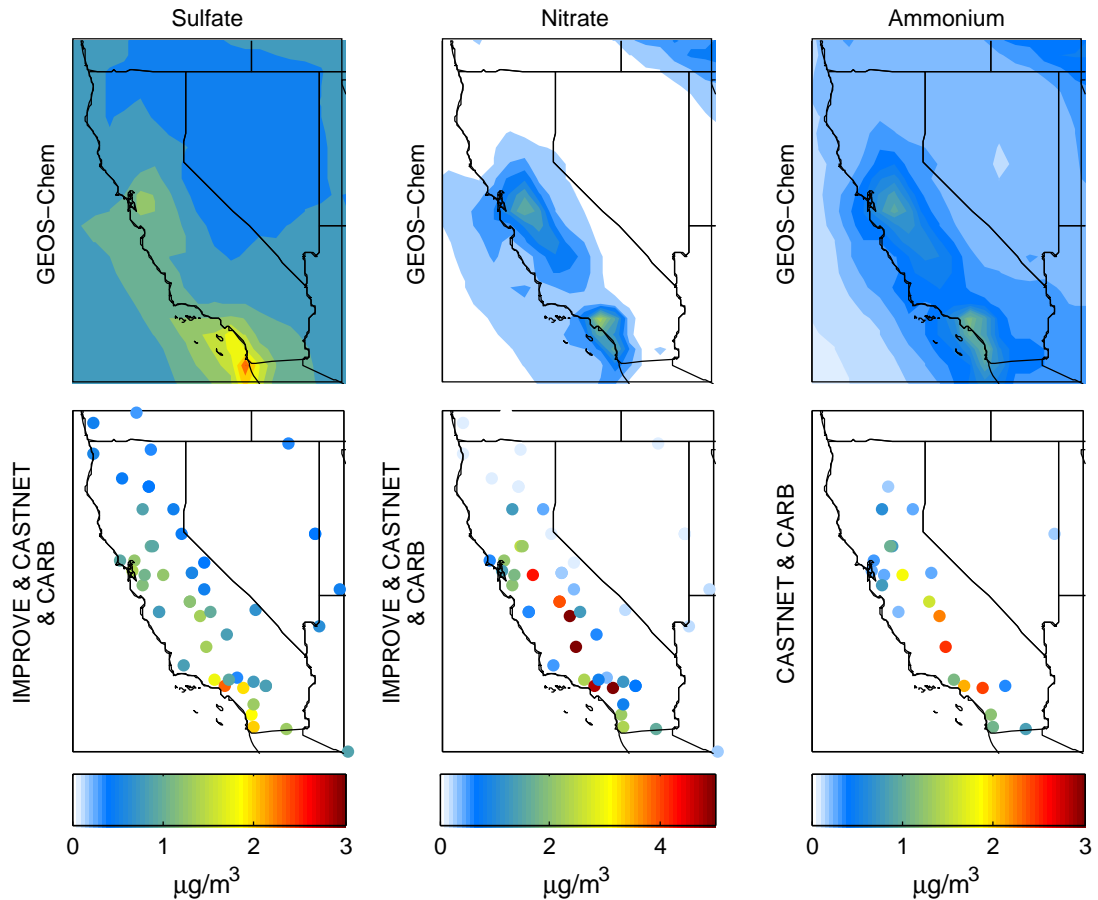

Fig. 5. Same as Fig. 4, but in detail for California.

Fig. 5. Scatter plots of predicted versus measured annual concentrations are shown in Fig. 6. The normalized mean biases (NMB) of predicted seasonal and annual concentrations are summarized in Table 2, where NMB $=\left(\Sigma\left(P_{i}-O_{i}\right) / \Sigma O_{i}\right) \times$ $100 \%$, where $P_{i}$ is the predicted and $O_{i}$ the observed seasonal average concentration, and the summation is over all measurement sites.

Predicted annual sulfate concentrations are in reasonable agreement with IMPROVE, CASTNET and CARB measure- ments (Fig. 6), with an NMB of $+18 \%$ for the continental US excluding California and $+3 \%$ for California. For California, the slope of the linear regression through the origin is actually less than 1, although the NMB is positive. Although this seems to be a contradiction, it reflects the fact that a straight line through the origin does not fit the scatter plot very well because there are just a few data points where the predicted concentration is substantially below the measured concentration, but there are a large number of data 

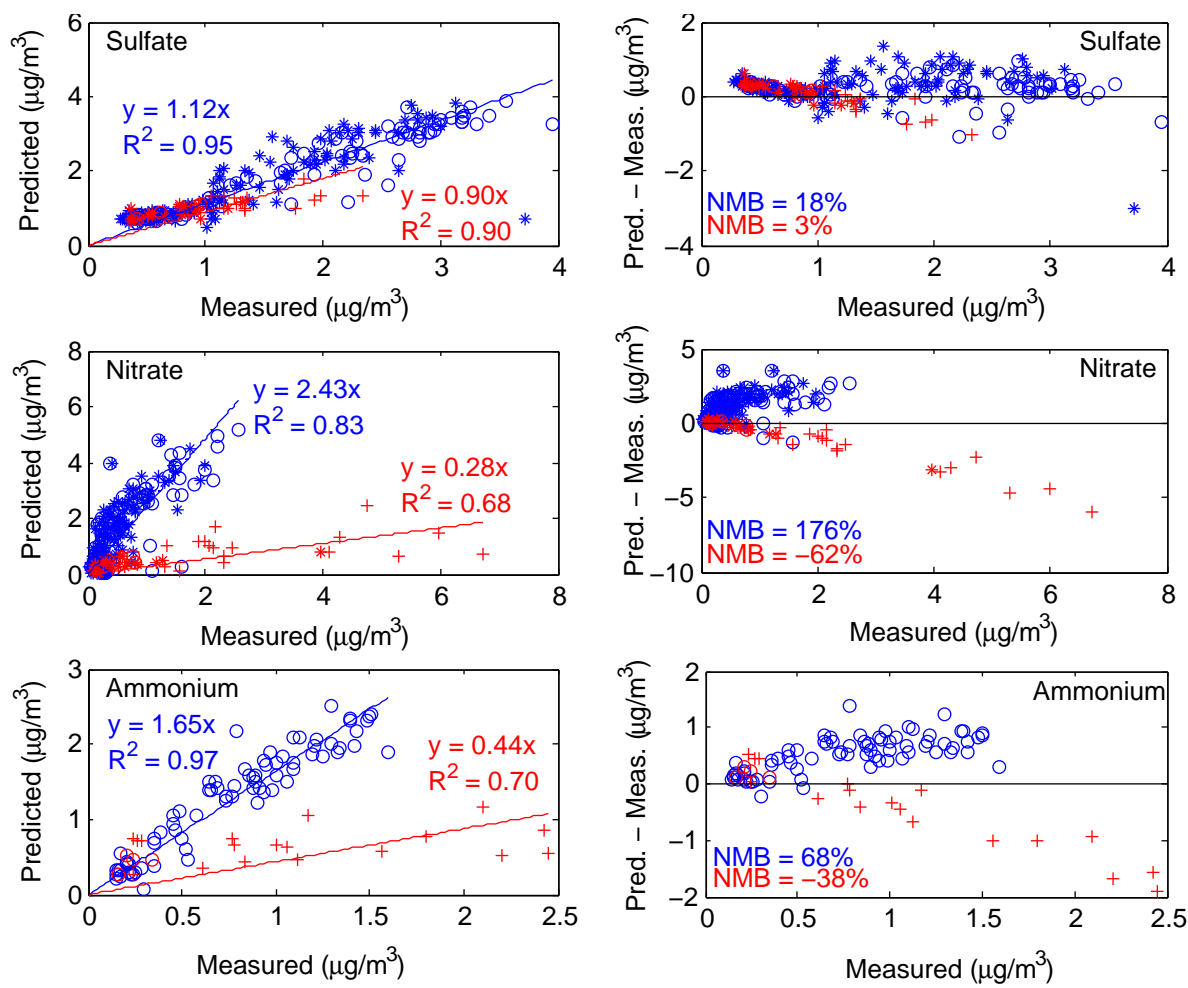

\begin{tabular}{|llll|}
\hline$*$ & IMPROVE (Non-Calif) & $*$ & IMPROVE (Calif) \\
& CASTNET (Non-Calif) & $\circ$ & CASTNET (Calif)
\end{tabular}

Fig. 6. Predicted versus measured annual mean concentrations (left panels) and difference between predicted and measured versus measured annual mean concentrations (right panels) for 2009. Each data point corresponds to an observed concentration at a measurement site along with the predicted concentration in the GEOS-Chem grid box containing the measurement site. Measured concentrations are IMPROVE $\left(\mathrm{PM}_{2.5}\right)$, CASTNET (TPM), and CARB $\left(\mathrm{PM}_{2.5}\right)$. Red regression lines and normalized mean biases (NMB) are for California sites only. Blue regression lines and NMB are for all sites excluding California. Coefficients of determination, $R^{2}$, calculated for regression through the origin (Montgomery et al., 2006).

points for which the predicted concentrations are very close to or just slightly higher than those measured (top right panel of Fig. 6). There is substantial over-prediction, with NMB of $+176 \%$ and $+68 \%$, respectively, in the predicted annual nitrate and ammonium annual concentrations over the US excluding California. The bias in nitrate predictions in the eastern and midwestern states has a significant seasonal variation, with the highest overprediction in the summer and autumn (Table 2). On the other hand, in California, there is a substantial under-prediction of annual nitrate and ammonium concentrations, with NMB of $-62 \%$ and $-38 \%$, respectively, and the panels on the right side of Fig. 6 show that the magnitude of the negative bias increases as the measured concentration increases.

Figure 7 shows monthly mean predicted and measured inorganic aerosol concentrations at Bondville, IL, in the region of highest predicted nitrate concentrations in the Midwest, and at Fresno, CA and Riverside, CA. At all three sites, predicted sulfate concentrations agree reasonably well with measured concentrations in magnitude and in the pattern of seasonal variation over the course of the year, with NMB values ranging from -36 to $9 \%$ (where the NMB at each site is calculated from the monthly mean predictions and observations at that site). Predicted nitrate and ammonium concentrations display similar patterns in comparison with observations at all three sites. At Bondville, nitrate and ammonium are over-predicted in all months except February and March, with NMB of $+67 \%$ and $+41 \%$ for nitrate and ammonium, respectively. At Riverside, nitrate and ammonium are underpredicted in all months, with NMB of $-75 \%$ and $-65 \%$, respectively. At Fresno, nitrate is under-predicted in all months (NMB of $-81 \%$ ) and ammonium is under-predicted in all months except April, June and July (NMB of $-64 \%$ ). At Fresno, there is a very strong seasonal variation in observed nitrate which is not reflected in the model predictions; predicted January average nitrate concentration at Fresno is less than one tenth of the observed January average nitrate concentration. 
Table 2. Normalized mean bias (\%) of predicted 2009 seasonal concentrations relative to measurements (IMPROVE, CASTNET, CARB),

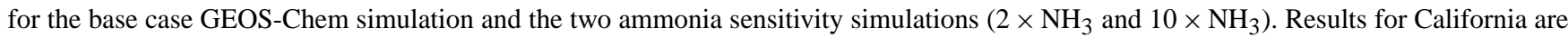
presented separately for the two regions shown in Fig. 11.

\begin{tabular}{|c|c|c|c|c|c|c|c|}
\hline Aerosol species & Region & Simulation & DJF & MAM & JJA & SON & Annual \\
\hline \multirow[t]{9}{*}{ Sulfate } & \multirow[t]{3}{*}{ USA excluding California } & Base Case & -3 & +17 & +23 & +32 & +18 \\
\hline & & $2 \times \mathrm{NH}_{3}$ & -0.1 & +18 & +23 & +34 & +19 \\
\hline & & $10 \times \mathrm{NH}_{3}$ & +4 & +19 & +229 & +36 & +21 \\
\hline & \multirow[t]{3}{*}{ California (Region A) } & Base Case & +67 & -14 & +11 & -1 & +6 \\
\hline & & $2 \times \mathrm{NH}_{3}$ & +67 & -14 & +12 & -1 & +6 \\
\hline & & $10 \times \mathrm{NH}_{3}$ & +69 & -14 & +12 & -1 & +6 \\
\hline & \multirow{3}{*}{ California (Region B) } & Base Case & -27 & -12 & +27 & -4 & -2 \\
\hline & & $2 \times \mathrm{NH}_{3}$ & -27 & -12 & +27 & -4 & -2 \\
\hline & & $10 \times \mathrm{NH}_{3}$ & -26 & -12 & +26 & -4 & -2 \\
\hline \multirow[t]{9}{*}{ Nitrate } & \multirow[t]{3}{*}{ USA excluding California } & Base Case & +147 & +85 & +319 & +296 & +176 \\
\hline & & $2 \times \mathrm{NH}_{3}$ & +248 & +209 & +654 & +556 & +334 \\
\hline & & $10 \times \mathrm{NH}_{3}$ & +463 & +539 & +1415 & +1095 & +691 \\
\hline & \multirow[t]{3}{*}{ California (Region A) } & Base Case & -66 & -65 & -34 & -50 & -55 \\
\hline & & $2 \times \mathrm{NH}_{3}$ & -35 & -31 & +26 & -4 & -13 \\
\hline & & $10 \times \mathrm{NH}_{3}$ & +84 & +91 & +217 & +144 & +130 \\
\hline & \multirow{3}{*}{ California (Region B) } & Base Case & -73 & -47 & -41 & -71 & -67 \\
\hline & & $2 \times \mathrm{NH}_{3}$ & -62 & -19 & -7 & -56 & -51 \\
\hline & & $10 \times \mathrm{NH}_{3}$ & -41 & +54 & +101 & -16 & -12 \\
\hline \multirow[t]{9}{*}{ Ammonium } & \multirow[t]{3}{*}{ USA excluding California } & Base Case & +63 & +48 & +59 & +109 & +68 \\
\hline & & $2 \times \mathrm{NH}_{3}$ & +118 & +93 & +102 & +184 & +122 \\
\hline & & $10 \times \mathrm{NH}_{3}$ & +232 & +195 & +179 & +32 & +229 \\
\hline & \multirow[t]{3}{*}{ California (Region A) } & Base Case & -59 & -48 & -12 & -33 & -38 \\
\hline & & $2 \times \mathrm{NH}_{3}$ & -41 & -29 & +15 & -7 & -16 \\
\hline & & $10 \times \mathrm{NH}_{3}$ & +23 & +32 & +94 & +73 & +54 \\
\hline & \multirow[t]{3}{*}{ California (Region B) } & Base Case & -68 & +12 & +51 & -46 & -38 \\
\hline & & $2 \times \mathrm{NH}_{3}$ & -58 & +36 & +75 & -33 & -24 \\
\hline & & $10 \times \mathrm{NH}_{3}$ & -40 & +94 & +140 & -1 & +8 \\
\hline
\end{tabular}

Figure 8 shows the partitioning between monthly predicted aerosol and gas-phase nitrate and ammonia at the Fresno, Riverside, and Bondville sites. The annual average concentrations of total ammonia (gas phase ammonia plus aerosol ammonium, expressed as $\mathrm{NH}_{3}$ ) and total nitrate (gas phase nitric acid plus aerosol nitrate, expressed as $\mathrm{HNO}_{3}$ ) are similar at the Riverside and Bondville locations, with $7.9 \mu \mathrm{g} \mathrm{m}^{-3}$ total nitrate and $1.8 \mu \mathrm{g} \mathrm{m}^{-3}$ total ammonia at Riverside, compared to $8.9 \mu \mathrm{g} \mathrm{m}^{-3}$ total nitrate and $2.4 \mu \mathrm{g} \mathrm{m}^{-3}$ total ammonia at Bondville. Since Bondville is generally colder and more humid than Riverside, a larger fraction of total nitrate and ammonia exist in the aerosol phase at Bondville (Fig. 8). At Fresno, the annual average concentration of total ammonia is $2.3 \mu \mathrm{g} \mathrm{m}^{-3}$, similar to the other two sites, but the annual average total nitrate is only $4.0 \mu \mathrm{g} \mathrm{m}^{-3}$, approximately half the concentration at Riverside and Bondville.

\subsection{Nitrate over-prediction in the Midwest/East}

Over-prediction of nitrate and ammonium aerosol in the eastern and midwestern states in this study is consistent with re- sults found by Zhang et al. (2012) and Heald et al. (2012). Nitrate aerosol is formed in thermodynamic equilibrium with gas-phase ammonia and nitric acid. The partitioning between the gas phase and aerosol phase nitrate is determined by the relative abundances of ammonia and nitric acid, as well as by the temperature and relative humidity, with equilibrium shifting towards the aerosol phase in colder and more humid conditions. If ammonia concentrations are low compared with the available nitric acid, then in thermodynamic equilibrium much of the $\mathrm{HNO}_{3}$ will remain in the gas phase and nitrate aerosol formation is ammonia-limited. Conversely, if $\mathrm{HNO}_{3}$ concentrations are low compared with the available ammonia, then nitrate aerosol formation is nitric acid-limited.

Zhang et al. (2012) suggest that GEOS-Chem may overpredict nitrate concentrations owing to an overestimate of nighttime nitric acid formation through heterogeneous $\mathrm{N}_{2} \mathrm{O}_{5}$ hydrolysis. However, the reduction of the $\mathrm{N}_{2} \mathrm{O}_{5}$ uptake coefficient, $\gamma$, by a factor of 10 in the current simulation did not reduce substantially the nitrate bias compared with another identical simulation (results not shown) using the standard GEOS-Chem values for $\gamma$ : the NMB in predicted 

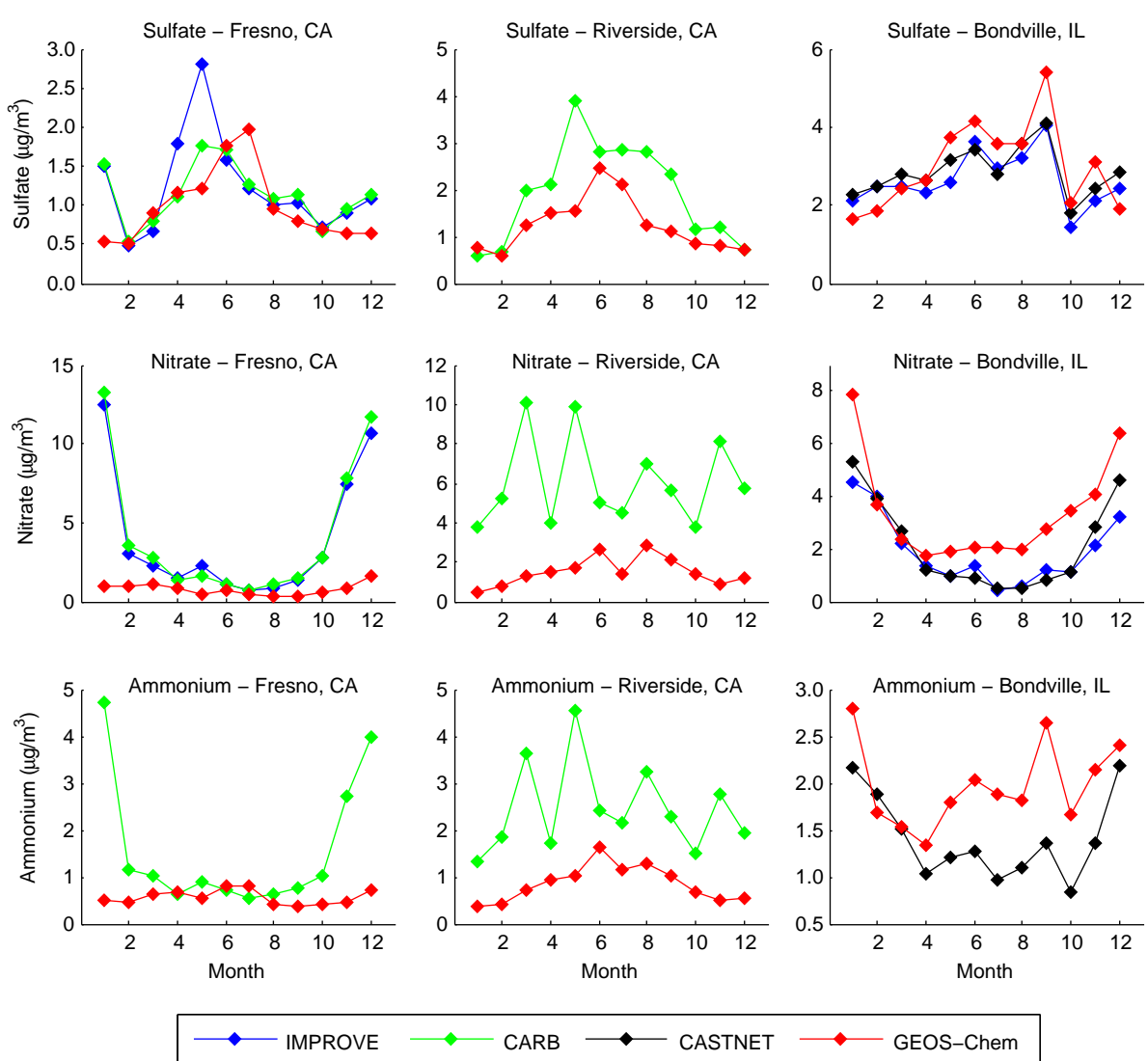

Fig. 7. 2009 monthly mean predicted and measured aerosol sulfate, nitrate, and ammonium concentrations at selected sites.
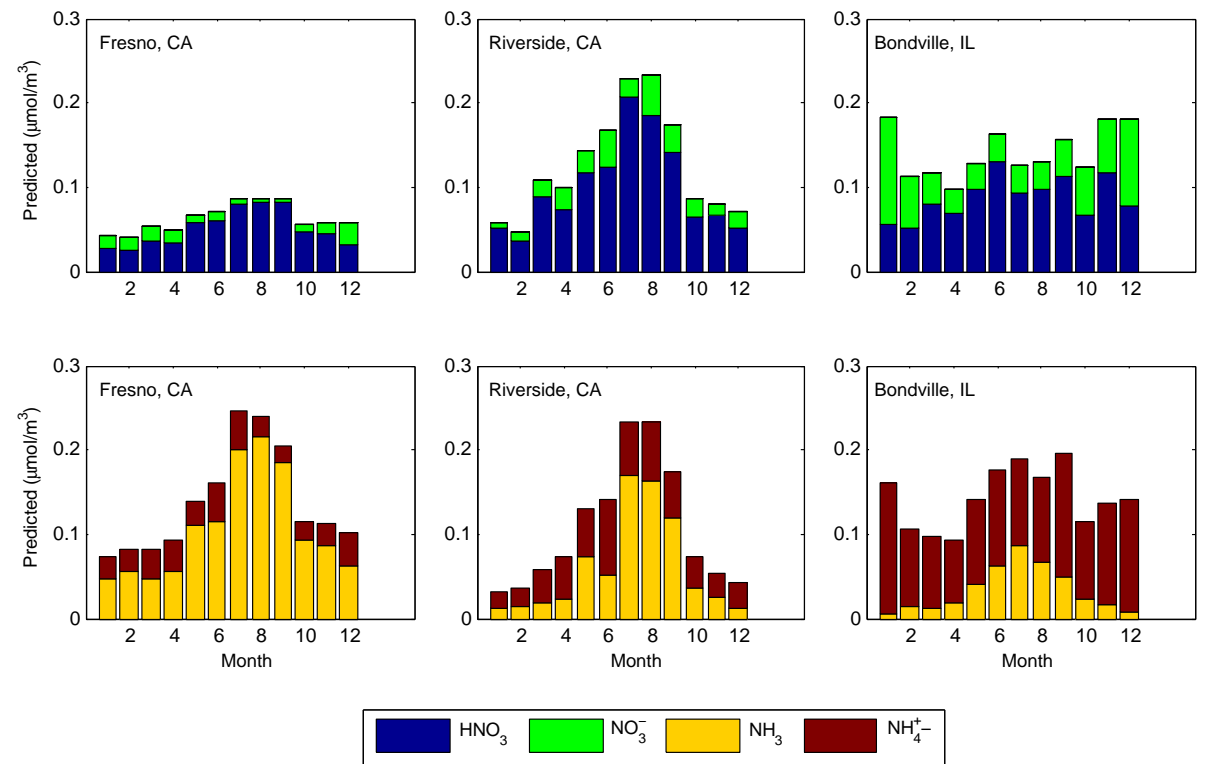

Fig. 8. Predicted 2009 monthly mean concentrations of gas-phase nitric acid, nitrate aerosol, gas-phase ammonia, and ammonium aerosol at selected sites. Note that gas-particle thermodynamic equilibrium is calculated to hold over each 20 min time step of the model. The monthly mean concentrations presented in this figure represent an average of the individual 20-min equilibria over all the hours of each month, and thus do not satisfy gas-particle equilibrium in the aggregate. 

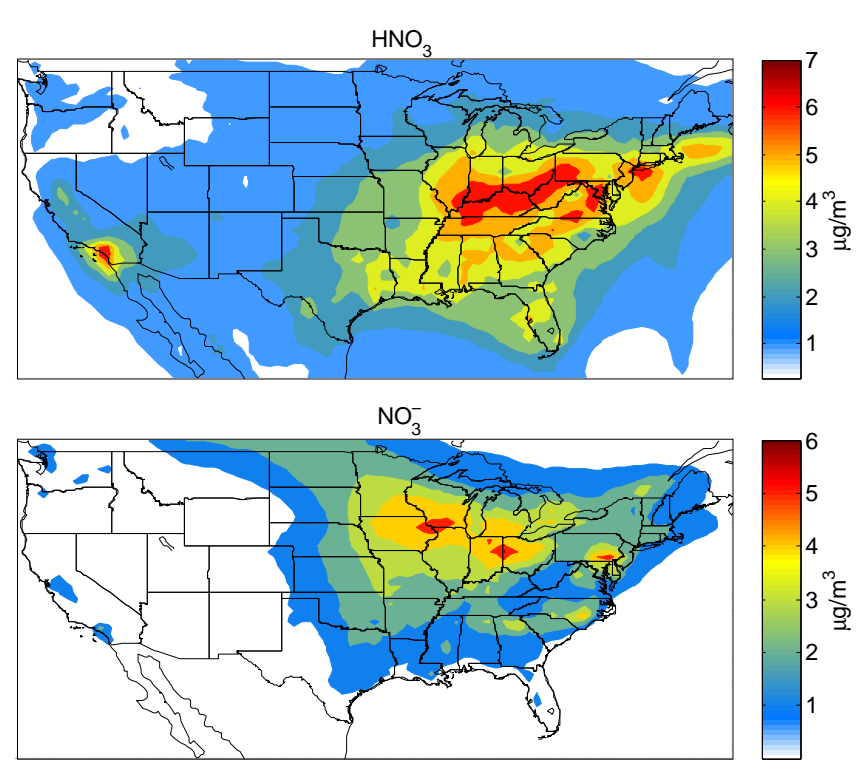

Fig. 9. Predicted 2009 annual mean concentrations of $\mathrm{HNO}_{3}$ (upper panel) and nitrate aerosol (lower panel).

annual nitrate over the continental US (excluding California) is $+176 \%$ (Table 2) when $\gamma$ is reduced by a factor of 10 , compared with an NMB of $+196 \%$ when the standard $\gamma$ values are used. These results suggest that an overestimate of heterogeneous $\mathrm{N}_{2} \mathrm{O}_{5}$ hydrolysis does not fully account for the nitrate bias.

Heald et al. (2012) found that GEOS-Chem simulation of nitrate aerosol over the midwestestern and eastern states is nitric acid-limited and that the positive nitrate bias is likely linked with an overestimate of nitric acid concentrations: when they reduced nitric acid concentrations to $75 \%$ of their simulated values in GEOS-Chem, this reduction corrected the bias in simulated nitrate and ammonium aerosol over the Midwest and East. In addition to the uncertainties in $\mathrm{N}_{2} \mathrm{O}_{5}$ hydrolysis, Heald et al. (2012) investigated other possible causes for an overestimate of nitric acid concentrations, including: uncertainties in daytime formation of $\mathrm{HNO}_{3}$ arising from uncertainties in emissions of $\mathrm{NO}_{\mathrm{x}}$, concentrations of $\mathrm{OH}$, or the rate of $\mathrm{NO}_{2}$ oxidation by $\mathrm{OH}$, and uncertainties in the dry deposition removal rates of nitric acid. They found that none of these uncertainties could fully account for the reduction in $\mathrm{HNO}_{3}$ required to correct the nitrate bias. Overprediction of nitrate in the midwestern and eastern states remains to be explained.

\subsection{Nitrate under-prediction in California}

Figure 9 shows predicted annual $\mathrm{HNO}_{3}$ and nitrate aerosol concentrations over the United States. Predicted concentrations of both $\mathrm{HNO}_{3}$ and nitrate aerosol are high over the midwestern and eastern states. However, in southern California, predicted $\mathrm{HNO}_{3}$ concentrations are among the highest in the country but this strong maximum is not reflected in the predicted nitrate aerosol concentrations, suggesting that the nitrate simulation in this region may be ammonia-limited.

The large uncertainties in the ammonia emissions inventory and seasonal scaling factors used in GEOS-Chem could potentially result in a substantial underestimate of ammonia emissions and concentrations, along with a corresponding underestimate of nitrate aerosol in regions where simulated conditions are ammonia-limited. In their study of aircraft data from the CalNex 2010 experiment, Nowak et al. (2012) found that ammonia emissions from dairy facilities in Southern California have a significant effect on nitrate aerosol formation, shifting the $\mathrm{NH}_{4} \mathrm{NO}_{3}$ equilibrium towards the particle phase and resulting in higher nitrate aerosol concentrations downwind of the dairy facilities. They also compared the CalNex aircraft data to NEI 2005 and CARBARCTAS 08 (Huang et al., 2010) emissions inventories of ammonia in the South Coast Air Basin and found that both emissions inventories underestimate ammonia emissions relative to emissions estimates derived from the aircraft data. In the NEI 2005 inventory, which is used in GEOS-Chem, ammonia emissions from automobiles and dairy facilities in this region are 38 and 1 metric tonnes per day, respectively, compared to 56 and 11 tonnes per day, respectively, in the CARBARCTAS 08 inventory. Both these estimates are much lower than the emissions estimates derived by Nowak et al. (2012) from CalNex, of 38 to 86 tonnes per day from automobiles and 33 to 176 tonnes per day from dairy facilities.

We conducted a sensitivity analysis with GEOS-Chem, simulating the year 2009 with anthropogenic emissions of ammonia increased by a factor of two (" $2 \times \mathrm{NH}_{3}$ " simulation) and by a factor of ten (" $10 \times \mathrm{NH}_{3}$ " simulation). Figure 10 shows the ratios of the predicted annual nitrate concentrations in the ammonia sensitivity simulations to the base case predicted annual nitrate concentrations. In the upper panel, which displays the results for the $2 \times \mathrm{NH}_{3}$ simulation, the ratio of predicted concentrations to base case predicted concentrations is close to two in the red areas, indicating that a doubling of ammonia emissions yields a doubling of predicted nitrate and thus the modeled nitrate is ammonialimited in these areas. In the lower panel of Fig. 10, showing the results for the $10 \times \mathrm{NH}_{3}$ simulation, the green, yellow and blue areas show the regions where predicted nitrate is sensitive to additional ammonia emissions beyond a factor of two increase, and the red areas show the regions where a tenfold increase in ammonia emissions yields a tenfold increase in predicted nitrate, indicating ammonia limitation over an order of magnitude increase in ammonia emissions.

Figure 11 summarizes the average ammonia sensitivity of predicted nitrate in California. The subset of California labeled "Region A" is an area of high ammonia sensitivity on average, in which predicted annual nitrate concentrations increase by $60 \%$ or more above the base case when ammonia emissions are doubled in GEOS-Chem. The subset of California labeled "Region B" is an area of lower ammonia sensitivity on average, in which predicted annual nitrate 


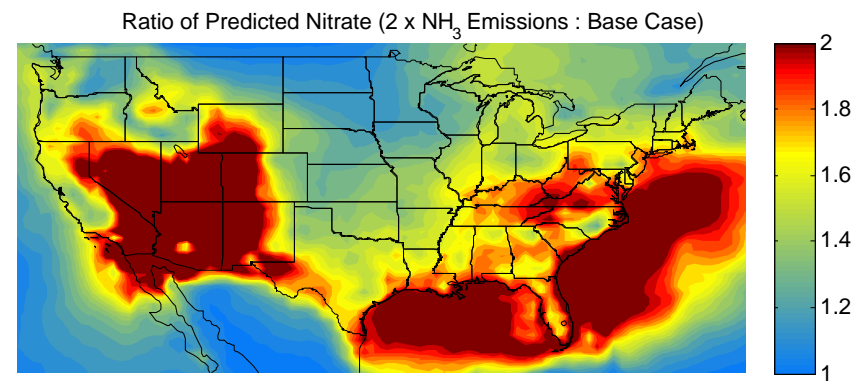

Ratio of Predicted Nitrate (10 $\times \mathrm{NH}_{3}$ Emissions : Base Case)

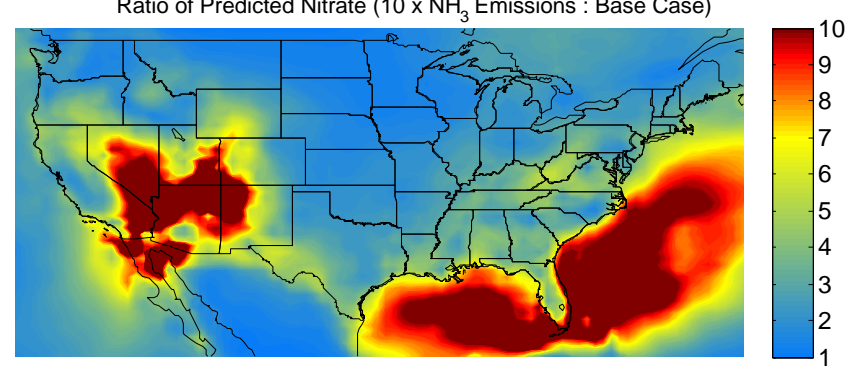

Fig. 10. Ratio of predicted 2009 annual nitrate concentrations in ammonia sensitivity simulations to base case predicted annual nitrate concentrations.

concentrations increase by less than $60 \%$ when ammonia emissions are doubled. In each of these regions, the thermodynamic equilibrium between gas-phase and aerosol-phase nitrate is computed at each timestep and grid cell, so within Region A there will be some locations and timesteps where the ammonia sensitivity is low, and conversely for Region B. However, Fig. 11 shows that, on average, there are two distinct regions corresponding to the limiting factor (ammonia or nitric acid) in the simulation of nitrate in California.

Region B covers approximately the central valley of California, including Fresno, while Region A covers the rest of the state, including Riverside and all of southern California. The monthly predicted nitrate at Fresno and Riverside is shown in Fig. 12 for the ammonia sensitivity simulations, along with the observed nitrate. At Fresno, a double or even tenfold increase in ammonia emissions is not sufficient to simulate the high wintertime nitrate concentrations observed at this location; this result is consistent with the low levels of predicted total nitrate relative to the predicted total ammonia at this location (Fig. 8). At Riverside, a doubling of ammonia emissions roughly doubles the predicted nitrate concentrations, but the predicted concentrations are still below the measured concentrations throughout the year. A tenfold increase in ammonia emissions yields predicted concentrations that are within the overall range of measured concentrations throughout the year, although the month to month variations are not captured as well as the annual average.

Table 2 summarizes the normalized mean biases in seasonal and annual predicted aerosol concentrations in the ammonia sensitivity simulations. In the ammonia sensitive Region $\mathrm{A}$ of California, the magnitude of the negative nitrate

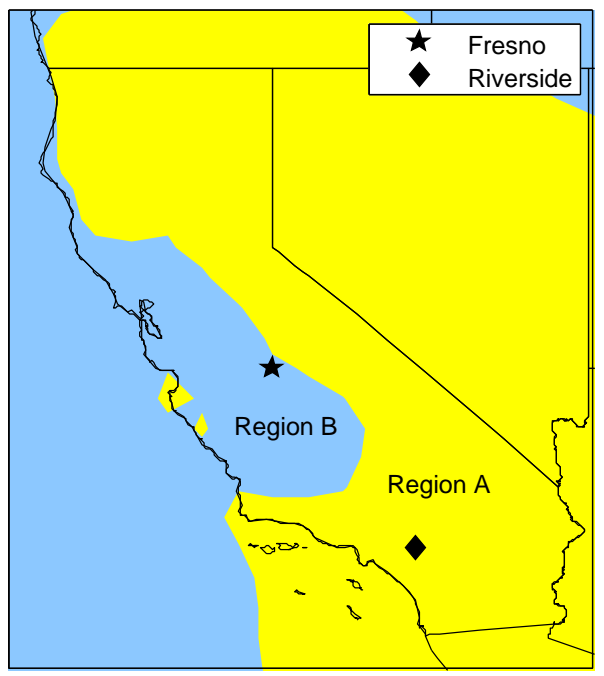

Fig. 11. California regions of high (Region A) and low (Region B) ammonia sensitivity in predicted nitrate. Region A (yellow areas in California) comprises the grid points for which predicted 2009 annual nitrate concentrations increase by $60 \%$ or more above the base case when ammonia emissions are doubled in GEOS-Chem. Region B (blue areas in California) comprises the grid points for which predicted 2009 annual nitrate concentrations increase by less than $60 \%$ when ammonia emissions are doubled in GEOS-Chem).

bias is substantially reduced with a doubling of ammonia emissions (annual average NMB of $-13 \%$ in the $2 \times \mathrm{NH}_{3}$ simulation, compared to $-55 \%$ in the base case). When ammonia emissions are increased tenfold, there are large positive biases in the predicted nitrate in Region A in all seasons, with NMB of $+130 \%$ in the annual average. These results indicate that in order to simulate observed nitrate aerosols in Region A, the annual total ammonia emissions in GEOSChem need to be increased by a factor of approximately two or slightly higher.

The seasonal biases in Table 2 indicate that an adjustment to the seasonality of ammonia emissions in GEOSChem (Park et al., 2004) could also improve the nitrate predictions in California Region A. Although a doubling of the annual total ammonia emissions reduces the annual average nitrate bias to $-13 \%$, the seasonal biases in this scenario are $-35 \%$ in winter and $+26 \%$ in summer. The seasonal scaling in GEOS-Chem (Park et al., 2004) is a single set of monthly scaling factors, which is applied uniformly to ammonia emissions over the whole country. These scaling factors attribute $73 \%$ of annual ammonia emissions to the 7 months of April through September, with the remaining $27 \%$ of annual emissions in the five month period of October through March. This seasonality is based primarily on ammonia emissions data from North Carolina (Aneja et al., 2000; Roelle and Aneja, 2002), an area that is likely representative of much of the US, but has colder winters and substantially less wintertime agricultural activity than California. The seasonal biases 

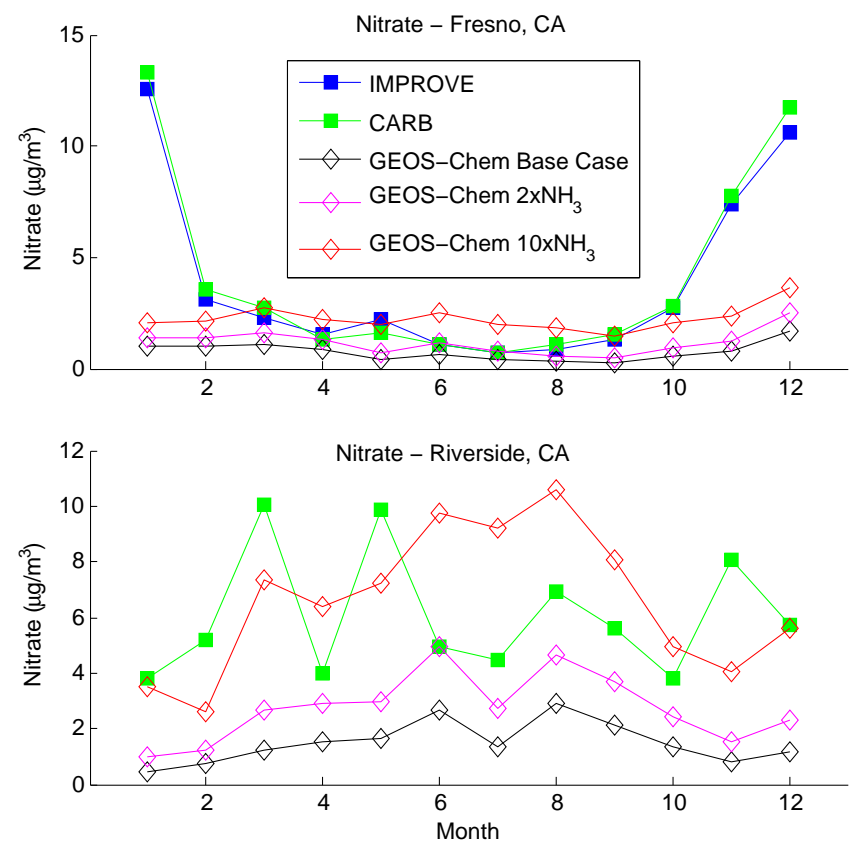

Fig. 12. 2009 monthly predicted aerosol nitrate at Fresno, CA and Riverside, CA in GEOS-Chem ammonia sensitivity simulations (base case, $2 \times \mathrm{NH}_{3}$ emissions, and $10 \times \mathrm{NH}_{3}$ emissions) compared with measured concentrations.

in nitrate shown in Table 2 and Fig. 12 suggest that in California, wintertime ammonia emissions comprise a larger fraction of the annual total, and summertime emissions comprise a smaller fraction of the annual total than the seasonality of Park et al. (2004). Since temperature and relative humidities are most favorable to nitrate formation in winter, this underestimate of the wintertime fraction of annual ammonia emissions in California is another likely cause for the underprediction of nitrate in California Region A.

In contrast with Region A, when ammonia emissions are doubled, predicted annual nitrate concentrations in Region $\mathrm{B}$ still have a large negative bias $\left(-51 \%\right.$ in the $2 \times \mathrm{NH}_{3}$ simulation, compared to $-67 \%$ in the base case) (Table 2). Even a tenfold increase in ammonia emissions yields predicted nitrate concentrations that are still biased low by $12 \%$ in the annual average. These results indicate that in Region B, the under-prediction of nitrate aerosol may be a result of underprediction of both ammonia and nitric acid in the central valley of California. Since nitrate aerosols are particularly sensitive to mixed layer depths, owing to the gas-particle equilibrium, the nitrate under-prediction could also arise in part from a potential regional overestimate of GEOS-5 mixed layer depths in the central valley due to unresolved topography in this region.

\subsection{Satellite measurements of ammonia}

To investigate the extent to which California ammonia emissions might be underestimated in GEOS-Chem, model pre- dictions are compared to satellite measurements of ammonia in California in 2009 from the Tropospheric Emissions Spectrometer (TES) (Shephard et al., 2011; Beer et al., 2008). TES is a high-resolution $\left(0.06 \mathrm{~cm}^{-1}\right)$ Fourier transform spectrometer onboard NASA's Aura satellite, in a sun-synchronous orbit with measurements at 01:30 and 13:30 LT. The spectrometer measures infrared radiation, and $\mathrm{NH}_{3}$ concentrations are retrieved using optimal estimation methods (Bowman et al., 2006; Rodgers, 2000) with the Line-By-Line Radiative Tansfer Model (LBLRTM) and the fast forward model (OSS-TES) (Clough et al., 2006; Moncet et al., 2008; Shephard et al., 2009). The ammonia data used in this study are from the TES Lite data product, Version 5 (http://avdc.gsfc.nasa.gov/index. php?site $=635564035 \& \mathrm{id}=10 \& \mathrm{go}=$ list $\&$ path $=/ \mathrm{NH} 3$ ).

To compare model predictions with satellite measurements, vertical profiles of predicted ammonia concentrations are sampled from GEOS-Chem hourly timeseries at each of the TES measurement locations and times. Each GEOSChem ammonia profile is interpolated from the model levels (47 vertical levels) onto the 15 vertical levels of the corresponding TES profile. The TES averaging kernel and a priori profile are applied to the interpolated profile using the equation $\hat{x}=x_{a}+A\left(x_{i}-x_{a}\right)$, where $\hat{x}$ is a "retrieved" profile representing what TES would measure if the interpolated GEOS-Chem profile $x_{i}$ were the true atmospheric state, $x_{a}$ is the TES a priori profile, $A$ is the TES averaging kernel representing the sensitivity of the retrieval to the true state, and the profiles $\hat{x}, x_{i}$ and $x_{a}$ are expressed as natural logarithm of the ammonia volume mixing ratios. An example TES retrieval, averaging kernel, and "retrieved" GEOS-Chem profile are shown in Fig. 13. Only TES retrievals with sufficiently high sensitivity (degrees of freedom for signal $\geq 0.5$ ) are included in the comparison, with a total of 142 retrievals over the year. Inherent in our comparison is a mismatch in scales, since the TES footprint is approximately $5 \times 8 \mathrm{~km}$ (Shephard et al., 2011), compared with the GEOS-Chem grid box size of approximately $56 \times 60 \mathrm{~km}$ in California. However, since the predominant sources of ammonia in California are agricultural sources emitting over extended areas, we expect that sub-grid scale variations will be relatively small.

At a given vertical level, a TES retrieved profile may be strongly influenced by the choice of a priori, and vertical columns are dependent on the selected a priori profile. To reduce the influence of the a priori profiles in the comparison of GEOS-Chem predictions with TES, representative volume mixing ratio (RVMR) values (Shephard et al., 2011) are compared for the retrieved profiles from TES and GEOS-Chem. The RVMR is a boundary layer average volume mixing ratio (VMR) which is weighted by the TES sensitivity to provide an ammonia concentration that is representative of the vertical region over which TES is most sensitive. Examples of RVMRs from retrieved TES and GEOS-Chem profiles are shown in Fig. 13. The TES RVMR values used in this comparison have a mean error of $45 \%$, where the RVMR error is 

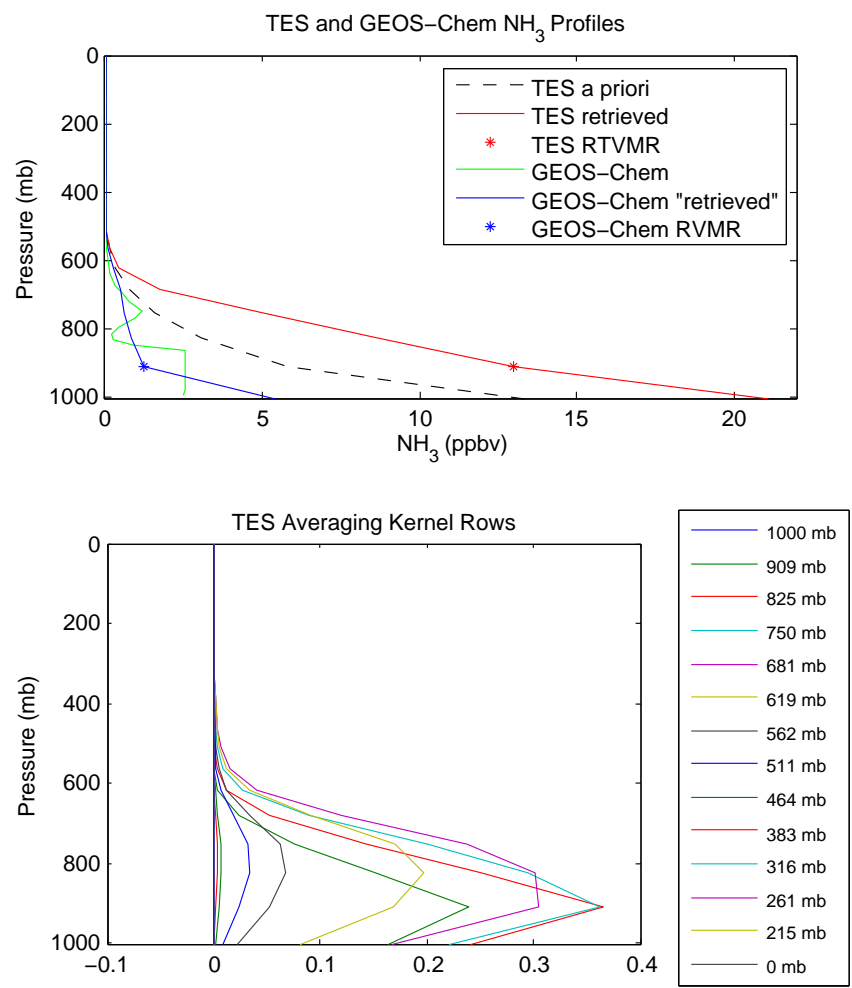

Fig. 13. Example ammonia profiles (TES, GEOS-Chem, and GEOS-Chem with the TES satellite operator applied) and TES averaging kernel, for the TES measurement at $\left(120.39^{\circ} \mathrm{W}, 37.35^{\circ} \mathrm{N}\right)$, 18 May 2009, 01:30 p.m. PST and corresponding GEOS-Chem grid box and timestep

the sum of the measurement and smoothing errors described by Shephard et al. (2011). The RVMR values from TES and GEOS-Chem over California are shown for each month of 2009 in Fig. 14. The TES RVMR values exceed those from GEOS-Chem at most locations throughout the year. The normalized mean bias of GEOS-Chem predicted RVMRs relative to TES RVMRs, over the 142 retrievals in the year, is $-79 \%$, which could indicate that ammonia emissions in California are underestimated in GEOS-Chem. This negative bias is consistent with the findings of Shephard et al. (2011), who compared ammonia predictions from a global GEOS-Chem simulation to TES RVMRs, and with the findings of Heald et al. (2012), who compare ammonia predictions from a North American GEOS-Chem simulation to vertical columns from the Infrared Atmospheric Sounding Interformeter (IASI) satellite measurements; in both of these studies, ammonia was under-predicted compared with satellite measurements.

The spatial and temporal coverage of TES ammonia measurements is relatively sparse, so an analysis of monthly or seasonal averages is not feasible. However, the TES measurements qualitatively indicate that the seasonal variation of ammonia emissions in California is less than the country-wide seasonality used in GEOS-Chem (Fig. 14), with a greater fraction of annual emissions occurring during the winter months than the currently assumed seasonality. Zhang et al. (2012) developed seasonal scaling factors for ammonia emissions based on measurements of total ammonia (ammonia plus ammonium aerosol) from the Midwest Ammonia Monitoring Project and the Southeastern Aerosol Research and Characterization; their analysis suggests a broadening of the summer peak, with enhanced springtime emissions. Comparison with IASI measurements also supports this increase in springtime emissions (Heald et al., 2012). The Zhang et al. (2012) seasonality, based on data from the midwest and southeast, improves the seasonal variations in predicted ammonia concentrations in these areas, and is likely representative of much of the country. In California, however, where ammonia emissions are high and winters are relatively warmer, our results suggest that seasonal variability of ammonia emissions differs substantially from those in the Midwest/East, and a seasonality customized to California conditions is needed in order to adequately simulate the observed nitrate concentrations in much of the state.

While we do not perform inverse modeling in the present study, inverse modeling represents a powerful method to assess the consistency between observed concentrations and emission inventories (Zhu et al., 2012; Turner et al., 2012).

\section{Conclusions}

Atmospheric chemical transport models (ACTMs) provide a powerful means to evaluate the extent to which predicted atmospheric gas and particle concentrations based on an assumed emission inventory agree with those actually observed. Prediction of aerosol levels over the US is a subject of intense interest, owing to efforts to achieve compliance with air quality standards and to assess the extent to which air quality is affected by long-range transport beyond the US border. Previous ACTM simulations of aerosol levels have exhibited mixed success in terms of agreement between predicted and observed concentrations. When predictions and observations do not agree, assessing the cause of the discrepancy may not be entirely straightforward, as both the emission inventory and representation of atmospheric processes may be implicated. The present study addresses the prediction of aerosol nitrate, sulfate, and ammonium levels over the US for 2009. Lack of agreement between observed and predicted levels can be traced to both emission inventory inaccuracies as well as model representation of nitric acid formation. The GEOS-Chem model employed here is the most widely used ACTM worldwide. The present study, and others like it, is valuable in pinpointing sources of modelmeasurement discrepancy and thereby lead to improvements in treatment of atmospheric processes and emission estimates. 

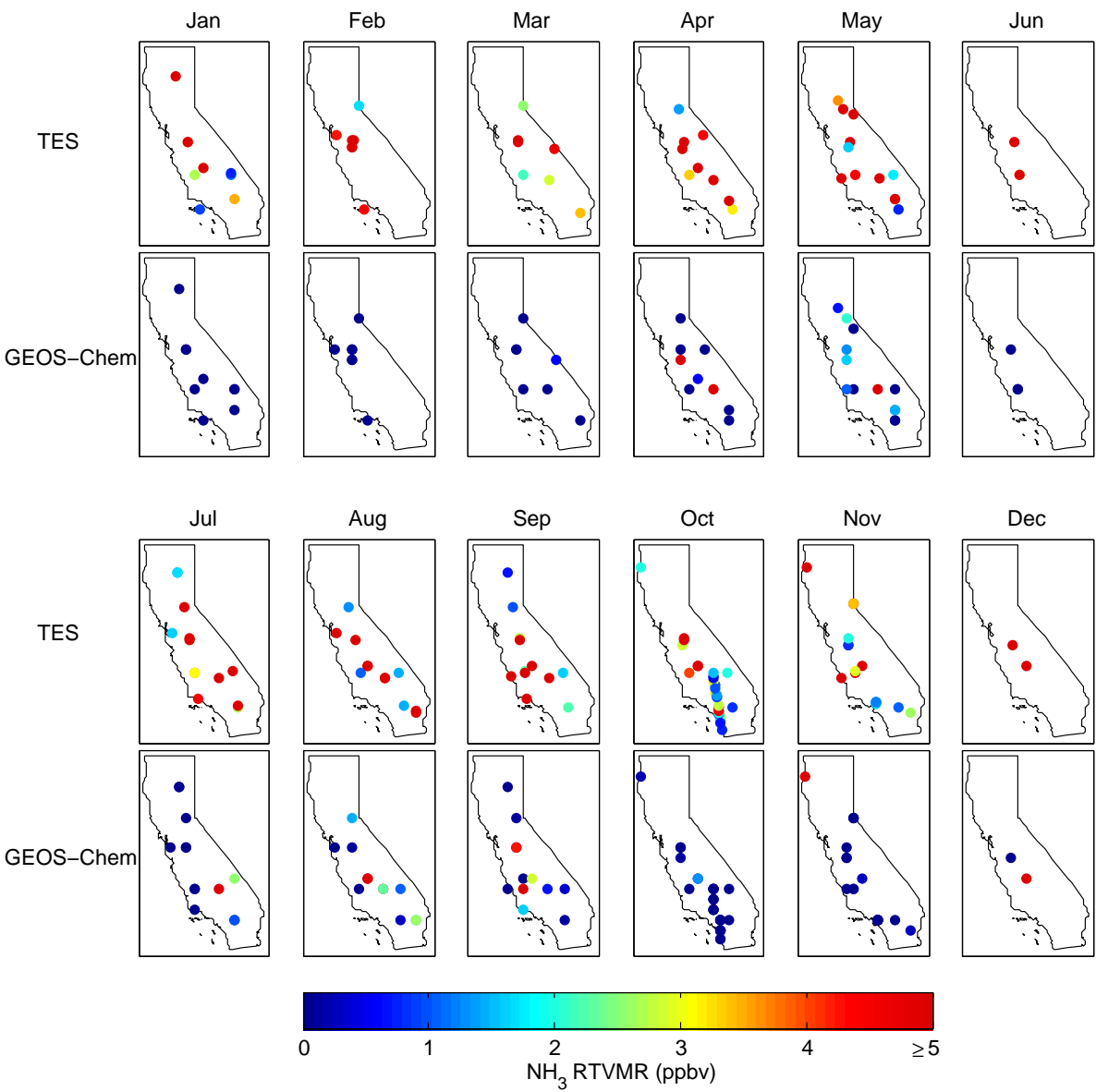

Fig. 14. Satellite-measured (TES) and predicted ammonia RVMR concentrations for 2009. Data points shown are individual measurements in each month; some data points overlap when there is more than one measurement at a location within a month.

Acknowledgements. The authors acknowledge the Clean Air Status and Trends Network (CASTNET), the Interagency Monitoring of Protected Visual Environments (IMPROVE), the California Air Resources Board (CARB), and NASA Jet Propulsion Laboratory for providing measurement data. Discussions with Joseph Ensberg, Karen Cady-Pereira, Debra Wunch, Paul Wennberg, Colette Heald and Havala Pye are greatly appreciated.

Edited by: M. Kopacz

\section{References}

Aneja, V. P., Chauhan, J. P., and Walker, J. T.: Characterization of atmospheric ammonia emissions from swine waste storage and treatment lagoons, J. Geophys. Res., 105, 11535-11545, doi:10.1029/2000JD900066, 2000.

Bauer, S. E., Koch, D., Unger, N., Metzger, S. M., Shindell, D. T., and Streets, D. G.: Nitrate aerosols today and in 2030: a global simulation including aerosols and tropospheric ozone, Atmos. Chem. Phys., 7, 5043-5059, doi:10.5194/acp-7-5043-2007, 2007.

Bey, I., Jacob, D. J., Yantosca, R. M., Logan, J. A., Field, B. D., Fiore, A. M., Li, Q. B., Liu, H. G. Y., Mickley,
L. J., and Schultz, M. G.: Global modeling of tropospheric chemistry with assimilated meteorology: model description and evaluation, J. Geophys. Res.-Atmos., 106, 23073-23095, doi:10.1029/2001JD000807, 2001.

Beer, R., Shephard, M. W., Kulawik, S. S., Clough, S. A., Eldering, A., Bowman, K. W., Sander, S. P., Fisher, B. M., Payne, V. H., Luo, M., Osterman, G. B., and Worden, J. R.: First satellite observations of lower tropospheric ammonia \& methanol, Geophys. Res. Lett., 35, L09801, doi:10.1029/2008GL033642, 2008.

Bouwman, A. F., Lee, D. S., Asman, W. A. H., Dentener, F. J., VanderHoek, K. W., and Olivier, J. G. J.: A global high-resolution emission inventory for ammonia, Global Biogeochem. Cy., 11, 561-587, doi:10.1029/97GB02266, 1997.

Bowman, K. W., Rodgers, C. D., Sund-Kulawik, S., Worden, J., Sarkissian, E., Osterman, G., Steck, T., Luo, M., Eldering, A., Shephard, M. W., Worden, H., Clough, S. A., Brown, P. D., Rinsland, C. P., Lampel, M., Gunson, M., and Beer, R.: Tropospheric emission spectrometer: Retrieval method and error analysis, IEEE T. Geosci. Remote, 44, 1297-1307, doi:10.1109/TGRS.2006.871234, 2006.

Chen, D., Wang, Y., McElroy, M. B., He, K., Yantosca, R. M., and Le Sager, P.: Regional CO pollution and export in China simulated by the high-resolution nested-grid GEOS-Chem model, Atmos. Chem. Phys., 9, 3825-3839, doi:10.5194/acp-9-3825-2009, 
2009.

Clough, S. A., Shephard, M. W., Worden, J., Brown, P. D., Worden, H. M., Luo, M., Rodgers, C. D., Rinsland, C. P., Goldman, A., Brown, L., Kulawik, S. S., Eldering, A., Lampel, M. C., Osterman, G., Beer, R., Bowman, K., Cady-Pereira, K. E., and Mlawer, E. J.: Forward Model and Jacobians for Tropospheric Emission Spectrometer Retrievals, IEEE T. Geosci. Remote, 44, 1308-1323, 2006.

Evans, M. J. and Jacob, D. J.: Impact of new laboratory studies of $\mathrm{N}_{2} \mathrm{O}_{5}$ hydrolysis on global model budgets of tropospheric nitrogen oxides, ozone, and OH, Geophys. Res. Lett., 32, L09813, doi:10.1029/2005GL022469, 2005.

Fountoukis, C. and Nenes, A.: ISORROPIA II: a computationally efficient thermodynamic equilibrium model for $\mathrm{K}^{+}$. $\mathrm{Ca}^{2+}-\mathrm{Mg}^{2+}-\mathrm{NH}_{4}^{+}-\mathrm{Na}^{+}-\mathrm{SO}_{4}^{2-}-\mathrm{NO}_{3}^{-}-\mathrm{Cl}^{-}-\mathrm{H}_{2} \mathrm{O}$ aerosols, Atmos. Chem. Phys., 7, 4639-4659, doi:10.5194/acp-7-4639-2007, 2007.

Heald, C. L., Collett Jr., J. L., Lee, T., Benedict, K. B., Schwandner, F. M., Li, Y., Clarisse, L., Hurtmans, D. R., Van Damme, M., Clerbaux, C., Coheur, P.-F., Philip, S., Martin, R. V., and Pye, H. O. T.: Atmospheric ammonia and particulate inorganic nitrogen over the United States, Atmos. Chem. Phys., 12, 10295-10312, doi:10.5194/acp-12-10295-2012, 2012.

Huang, M., Carmichael, G. R., Adhikary, B., Spak, S. N., Kulkarni, S., Cheng, Y. F., Wei, C., Tang, Y., Parrish, D. D., Oltmans, S. J., D’Allura, A., Kaduwela, A., Cai, C., Weinheimer, A. J., Wong, M., Pierce, R. B., Al-Saadi, J. A., Streets, D. G., and Zhang, Q.: Impacts of transported background ozone on California air quality during the ARCTAS-CARB period - a multi-scale modeling study, Atmos. Chem. Phys., 10, 6947-6968, doi:10.5194/acp-106947-2010, 2010.

Koracin, D. and Berkowicz, R.: Nocturnal Boundary Layer Height: Observations by Acoustic Sounders and Prediction in Terms of Surface Layer Parameters, Bound.-Lay. Meteorol., 43, 65-83, doi:10.1007/BF00153969, 1988.

Lin, J. T. and McElroy, M. B.: Impacts of boundary layer mixing on pollutant vertical profiles in the lower troposphere: Implications to satellite remote sensing, Atmos. Environ., 44, 17261739, doi:10.1016/j.atmosenv.2010.02.009, 2010.

Liu, H., Jacob, D. J., Bey, I., and Yantosca, R. M.: Constraints from ${ }^{210} \mathrm{~Pb}$ and ${ }^{7} \mathrm{Be}$ on wet deposition and transport in a global threedimensional chemical tracer model driven by assimilated meteorological fields, J. Geophys. Res.-Atmos., 106, 12109-12128, doi:10.1029/2000JD900839, 2001.

Liu, Shuyan and Xin-Zhong, Liang: Observed Diurnal Cycle Climatology of Planetary Boundary Layer Height, J. Climate, 23, 5790-5809, doi:10.1175/2010JCLI3552.1, 2010.

Macintyre, H. L. and Evans, M. J.: Sensitivity of a global model to the uptake of $\mathrm{N}_{2} \mathrm{O}_{5}$ by tropospheric aerosol, Atmos. Chem. Phys., 10, 7409-7414, doi:10.5194/acp-10-7409-2010, 2010.

Montgomery, D. C., Peck, E. A., and Vining, G. G.: Introduction to Linear Regression Analysis, 4th Edn., John Wiley \& Sons Inc., Hoboken, New Jersey, 2006.

Myhre, G., Grini, A., and Metzger, S.: Modelling of nitrate and ammonium-containing aerosols in presence of sea salt, Atmos. Chem. Phys., 6, 4809-4821, doi:10.5194/acp-6-4809-2006, 2006.

Moncet, J.-L., Uymin, G., Lipton, A. E., and Snell, H. E.: Infrared radiance modeling by optimal spectral sampling, J. Atmos. Sci.,
65, 3917-3934, 2008.

Nowak, J. B., Neuman, J., Bahreini, R., Middlebrook, A. M., Holloway, J., McKeen, S., Parrish, D., Ryerson, T., and Trainer, M.: Ammonia sources in the California South Coast Air Basin and their impact on ammonium nitrate formation, Geophys. Res. Lett., 39, L07804, doi:10.1029/2012GL051197, 2012.

Park, R. J., Jacob, D. J., Field, B. D., Yantosca, R. M., and Chin, M.: Natural and transboundary pollution influences on sulfate-nitrate-ammonium aerosols in the United States: implications for policy, J. Geophys. Res., 109, D15204, doi:10.1029/2003JD004473, 2004.

Pye, H. O. T., Liao, H., Wu, S., Mickley, L. J., Jacob, D. J., Henze, D. K., and Seinfeld, J.: Effect of changes in climate and emissions on future sulfate-nitrate-ammonium aerosol levels in the United States, J. Geophys. Res., 114, D01205, doi:10.1029/2008JD010701, 2009.

Rodgers, C. D.: Inverse methods for atmospheric Sounding: Theory and Practice, World Sci., Hackensack, NJ, 2000.

Roelle, P. A. and Aneja, V. P.: Characterization of ammonia emissions from soils in the upper coastal plain, North Carolina, Atmos. Environ., 36, 1087-2097, doi:10.1016/S13522310(01)00355-7, 2002.

Seinfeld, J. H. and Pandis, S.: Atmospheric Chemistry and Physics - From Air Pollution to Climate Change, 2nd Edn., John Wiley \& Sons Inc., Hoboken, New Jersey, 2006.

Shephard, M. W., Clough, S. A., Payne, V. H., Smith, W. L., Kireev, S., and Cady-Pereira, K. E.: Performance of the line-by-line radiative transfer model (LBLRTM) for temperature and species retrievals: IASI case studies from JAIVEx, Atmos. Chem. Phys., 9, 7397-7417, doi:10.5194/acp-9-7397-2009, 2009.

Shephard, M. W., Cady-Pereira, K. E., Luo, M., Henze, D. K., Pinder, R. W., Walker, J. T., Rinsland, C. P., Bash, J. O., Zhu, L., Payne, V. H., and Clarisse, L.: TES ammonia retrieval strategy and global observations of the spatial and seasonal variability of ammonia, Atmos. Chem. Phys., 11, 10743-10763, doi:10.5194/acp-11-10743-2011, 2011.

Sickles II, J. E. and Shadwick, D. S.: Precision of atmospheric dry deposition data from the Clean Air Status and Trends Network, Atmos. Environ., 36, 5671-5686, doi:10.1016/S13522310(02)00723-9, 2002.

Turner, A. J., Henze, D. K., Martin, R. V., and Hakami, A.: The spatial extent of source influences on modeled column concentrations of short-lived species, Geophys. Res. Lett., 39, L12806, doi:10.1029/2012GL051832, 2012.

van Donkelaar, A., Martin, R. V., Pasch, A. N., Szykman, J. J., Zhang, L., Wang, Y. X., and Chen, D.: Improving the accuracy of daily satellite-derived ground-level fine aerosol concentration estimates for North America, Environ. Sci. Technol., 46, 1197111978, doi:10.1021/es3025319, 2012.

Weseley, M. L.: Parameterization of surface resistances to gaseous dry deposition in regional-scale numerical models, Atmos. Environ., 23, 1293-1304, doi:10.1016/0004-6981(89)90153-4, 1989.

Wu, S, Mickley, L. J., Jacob, D. J., Logan, J. A., and Yantosca, R. M.: Why are there large differences between models in global budgets of tropospheric ozone?, J. Geophys. Res, 112, D05302, doi:10.1029/2006JD007801, 2007.

Zhang, L., Jacob, D. J., Knipping, E. M., Kumar, N., Munger, J. W., Carouge, C. C., van Donkelaar, A., Wang, Y. X., and Chen, D.: Nitrogen deposition to the United States: distribution, 
sources, and processes, Atmos. Chem. Phys., 12, 4539-4554, doi:10.5194/acp-12-4539-2012, 2012.

Zhang, L. M., Gong, S. I., Padro, J., and Barrie, L.: A size-segregated particle dry deposition scheme for an atmospheric aerosol module, Atmos. Environ., 35, 549-560, doi:10.1016/S1352-2310(00)00326-5, 2001.
Zhu, L., Henze, D. K., Cady-Pereira, K. E., Shephard, M. W., Luo, M., Pinder, R. W., Bash, J. O., and Jeong, G.: Constraining U.S. ammonia emissions using TES remote sensing observations and the GEOS-Chem adjoint model, J. Geophys. Res., submitted, 2012. 